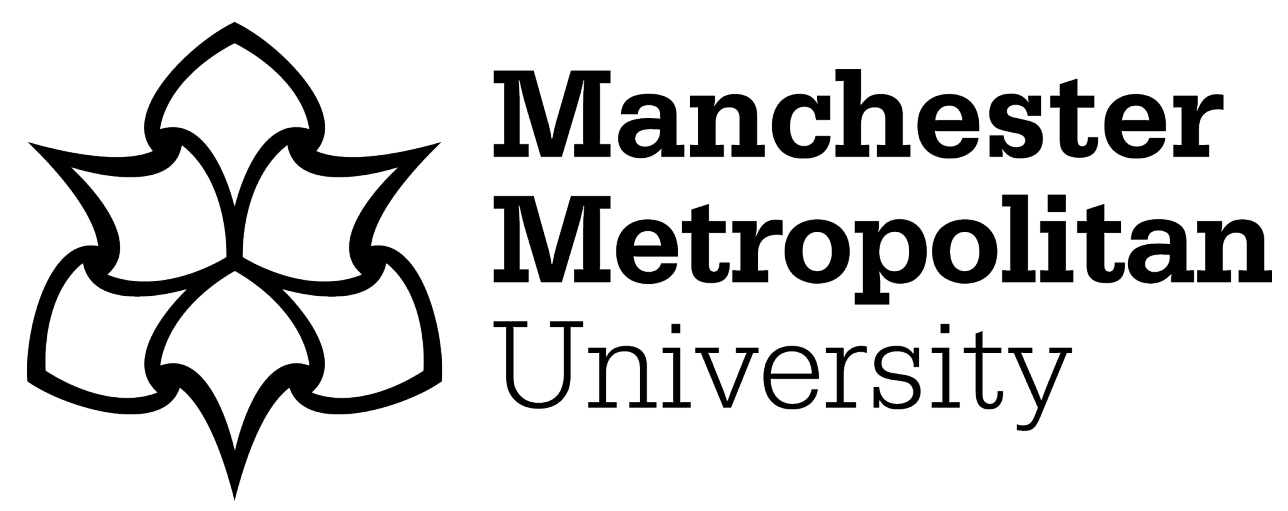

Siltori, Patricia FS, Rampasso, Izabela Simon, Martins, Vitor WB, Anholon, Rosley, Silva, Dirceu, Souza Pinto, Jefferson and Leal Filho, Walter (2021) Analysis of the motivations for ISO 9001:2015 adoption in the Brazilian business context. Quality Management Journal, 28 (2). pp. 76-85. ISSN 10686967

Downloaded from: https://e-space.mmu.ac.uk/628140/

Version: Accepted Version

Publisher: Informa UK Limited

DOI: https://doi.org/10.1080/10686967.2021.1886025

Please cite the published version 


\section{Analysis of the motivations for ISO 9001:2015 adoption in the Brazilian business context}

\section{Quality Management Journal 28(2):76-85 03 Apr 2021 DOI}

https://www.tandfonline.com/doi/full/10.1080/10686967.2021.1886025

Siltori, Patricia F. S. ${ }^{\text {a; }}$ Rampasso, Izabela Simon ${ }^{\mathrm{a}, b^{*}}$; Martins, Vitor W. B. ${ }^{\mathrm{a}}$ c; Anholon, Rosley; Silva, Dirceu ${ }^{\mathrm{d}}$; Souza Pinto, Jefferson ${ }^{\mathrm{a}, \mathrm{e}}$; Leal Filho, Walter $^{\mathrm{f}}$

${ }^{a}$ School of Mechanical Engineering, University of Campinas. Mendeleyev Street, 200. Campinas, Brazil; ${ }^{b}$ PNPD/CAPES Program, Doctoral Program in Sustainable Management Systems, Federal Fluminense University. Passo da Pátria Street, 156.

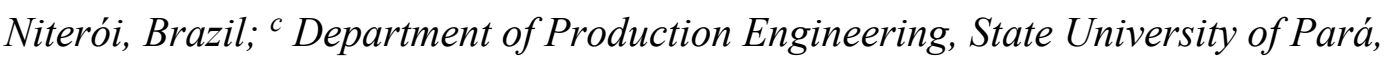
Travessa Dr. Enéas Pinheiro, 2626. Belém, Brazil; ' Faculty of Education, University of Campinas. Av. Bertrand Russell, 801. Campinas, Brazil; ${ }^{e}$ Federal Institute of São Paulo, Major Fernando Valle Street, 2013. Bragança Paulista, Brazil; ${ }^{f}$ Faculty of Life Sciences, Hamburg University of Applied Sciences, Ulmenliet 20, D-21033. Hamburg, Germany.

* Corresponding author: izarampasso@gmail.com (Izabela Simon Rampasso); Mendeleyev Street, 200. Campinas, Brazil. Phone: +55 19 3521-3398.

\section{Data Availability Statement}

The data that support the findings of this study are available on request from the corresponding author, ISR. The data are not publicly available due to do not compromise the privacy of research participants. 
This work was supported by the Coordenação de Aperfeiçoamento de Pessoal de Nível Superior - Brasil (CAPES) - Finance Code 001; processes 88882.435248/2019-01; and 88887.464433/2019-00; Conselho Nacional de Desenvolvimento Científico e Tecnológico (CNPq) 307536/2018-1; and 311530/2018-4; and Universidade do Estado do Pará (UEPA) 626/18.

\section{Biographical note}

Patricia Fernanda da Silva Siltori. Technologist in Industrial Production Management (IFSP-SP). Master in Mechanical Engineering and currently a PhD student at the State University of Campinas, Brazil (Unicamp). Research focus: sustainable manufacturing, sustainability in the context of industry 4.0 and management system.

Izabela Simon Rampasso holds B.Sc. in Economic Sciences at Pontifical Catholic University of Campinas (Brazil) and M.Sc. and PhD at University of Campinas (Brazil). Currently, she is postdoctoral researcher at Federal Fluminense University (Brazil) and researcher at University of Campinas.

Vitor W. B. Martins is currently Professor of the Department of Production Engineering - State University of Pará and PhD candidate in Mechanical Engineering at the University of Campinas. Experienced in Operations Management with focus on Logistics Sytems, Sustainability, Quality Management and Lean Production. He holds B.Sc in Production Engineering at the University of Amazônia (UNAMA) and M.Sc in Civil Engineering at the Federal University of Pará (UFPA).

Rosley Anholon is currently Professor of the Department of Manufacturing Engineering and Materials (University of Campinas, Brazil), experienced in Quality Management, Production Systems and Sustainability. He holds B.Sc., M.Sc. and PhD at University of Campinas. He has more than 60 publications in international journals.

Dirceu da Silva has experience in Administration and Education, with emphasis on quantitative methods for numerical data analysis and multivariate statistical analysis. He holds a B.Sc. in Physics and Mathematics, a M.Sc. in Physics and a PhD in Education at University of São Paulo (Brazil). Currently, he is professor at University of Campinas (Brazil). 
Jefferson de Souza Pinto is currently Professor of Federal Institute of Education, Science and Technology of São Paulo (IFSP, Brazil), experienced in Project Management, Supply Chain Management and Operations Management. Collaborating Professor of the School of Mechanical Engineering (University of Campinas, Brazil). He holds bachelor's degree in business administration, M.Sc. and PhD in Mechanical Engineering at University of Campinas. He has publications in national and international journals, congresses and books in business administration.

Walter Leal Filho is professor at Hamburg University of Applied Sciences and at Manchester Metropolitan University School of Science and the Environment. He has more than 500 publications to his credit.

Abstra

This study aims to analyse the reasons that motivate Brazilian companies to implement Quality Management Systems, according to ISO 9001:2015 requirements. Based on information collected in the literature, a questionnaire was developed and answered by professionals that work with the mentioned standard in their companies. An Exploratory Factor Analysis was conducted with the collected data to group the validated variables into two constructs that present the most part of information variance. These constructs were entitled "internal improvements related motives" and "market related motives". The findings of this research confirm and complement previous studies performed in Brazil and in other countries.

Keywords: Quality management; ISO 9001; Adoption motives; Motivation.

\section{Introduction}

Organizations need to survive in a highly complex environment that is subject to fast changes. These changes in general are related to new technologies imposed by the competitive market and to the new standards of consumer demands (Hadidi et al. 2017; Leong, Snyder, and Ward 1990; Gotzamani and Tsiotras 2002; Chou, Hao-Chun Chuang, and Shao 2014). In this reality, companies increasingly need an adaptive 
capacity, understanding the context in which they operate and developing new strategies that allow them to be ahead of their competitors (Youssef and Youssef 2018; Salem 2019; Sfreddo et al. 2018; Rampasso et al. 2017).

Competitiveness presents different aspects, either through lower cost, higher quality or differential in relation to a product or service offered. Regardless of the aspect, increments related to continuous improvement are always necessary (Nilssonwitell, Antoni, and Dahlgaard 2005; Molina, Lloréns Montes, and Del Mar Fuentes Fuentes 2004; Wilson and Campbell 2018). For some authors (Zrymiak 2017; del Castillo-Peces et al. 2018; Priede 2012), the adoption of a quality management system aligned with ISO 9001 requirements can greatly contribute to organizational competitiveness, independent of the aspect desired by the company. Sfreddo et al. (2018) corroborate with this perspective, concluding that there is a positive relationship between a quality management system implementation and organizational performance. Toke and Kalpande (2020) highlight that the ISO 9000 series is popular also for small and medium enterprises.

The ISO 9001 standard has long used the process management model and is increasingly being structured to identify all stakeholders and meet their objectives (Wilson and Campbell 2016; Su, Dhanorkar, and Linderman 2015; Sfreddo et al. 2018; Molina, Lloréns Montes, and Del Mar Fuentes Fuentes 2004; Wilson and Campbell 2018; Anholon et al. 2018, 2016). Since the 2015 version, this standard has given greater value to improving quality and not only the quality management system, since the latter is characterized as a mechanism to achieve results (Lizarelli, Toledo, and Alliprandini 2019; Wilson and Campbell 2018). The standard also became more flexible by not requiring mandatory documents, allowing companies to structure their management systems more freely (Rybski, Jochem, and Homma 2017; Wilson and 
Campbell 2016). Considering these changes, it is important to analyse the motivations for adopting the current version of the standard, whether by a company that seeks to update its recertification or a company that will implement the standard for the first time.

In 2015 version, ISO 9001 is divided into ten sections, seven of which have requirements to be met by companies within PDCA cycle logic. The main aspects related to the aforementioned requirements are: to understand the context into which the company is inserted and definition of stakeholders (section 4); leadership aspects (section 5); quality planning, risk analysis and change planning (section 6); resource, communication and competency management, as well as guidelines for documenting information (section 7); planning and control of operations, product development and issues related to non-compliance control (section 8); performance evaluation, internal audit and management processes (section 9); and actions aimed at continuous improvement (section 10) (ISO 2019).

If properly implemented, the Quality Management System proposed by ISO 9001: 2015 can provide several benefits, such as: better financial performance, increased organizational efficiency, better awareness of employees, greater efficiency in management control, improvements in processes and, as consequences, increased customer satisfaction and improved organization image (Tomic and Spasojevic Brkic 2019; Wilson and Campbell 2018). It is logical that the aforementioned benefits are usually related to the reasons why companies implement and maintain this management system, as reported by several authors (Santos et al. 2016; Murmura et al. 2018; E. L. Psomas 2013; Sun et al. 2019; E. Psomas and Antony 2015; Wilcock and Boys 2017; Tang and Kam 1999; Kafetzopoulos, Gotzamani, and Psomas 2013; Zaramdini 2007; Hadidi et al. 2017). 
Focusing on the motivations that lead companies to adopt the Quality Management Systems disseminated by ISO 9001.

Su et al. (2015) and Sun et al. (2019) argue that these motivations can be divided into external and internal. When companies adopt this system as a result of internal motivations, in general, better results are achieved and the benefits appear more solid and lasting. When motivations are associated with external issues, such as pressure from customers, greater difficulties are observed, as reported by Sampaio, Saraiva and Rodrigues (2009). Castka (2018) and Willar, Coffey and Trigunarsyah (2015) corroborate with the this point of view, stating that the reasons for adopting the standard are to drive business results.

In general, internal motivations have a more significant influence on all stages of QMS implementation and motivate employees considerably (Sun et al. 2019; Su, Dhanorkar, and Linderman 2015; Kakouris and Sfakianaki 2019; Williams 2004). Sampaio et al. (2009) corroborate the previous statements, concluding that business efficiency is directly related to the motivations that drive managers. There are authors that cite as motivations for adopting quality standards the reduction of operating costs, increased efficiency and predictability of processes that lead to better profits (Hadidi et al. 2017; Sun et al. 2019; Wilcock and Boys 2017). However, they point out that specific analyses need to be made for different countries and sectors, since cultural and market aspects can influence the reasons that influence companies in decision making.

According to Hadidi et al. (2017), Sun et al. (2019) and Wilcock and Boys (2017), in terms of countries, analyses have already been carried out to understand the reasons that lead companies to adopt and maintain quality management systems according to the guidelines proposed by ISO 9001, including a study conducted in Brazil by Maekawa, De Carvalho and De Oliveira (2013). Some studies have been 
carried out based on previous versions of the standard. However, new research about this theme are of great value and contribute to the expansion of debates. Briefly, such works will be presented below.

Maekawa et al. (2013) conducted a survey with 191 Brazilian organizations in order to understand the motivations, benefits and difficulties related their certification to the standard. According to their study, the main motivations were: internal improvements, productive efficiency, and greater reliability in the company's brand with consumers. Although the present research focuses on part of the theme worked by Maekawa et al. (2013), there are important differences to be mentioned. First, both studies have probabilistic sampling, with different samples and exploratory character. Thus, the more studies are developed, the more the debates on this topic can be expanded through confirmations and / or comparisons. Second, there is a time gap between studies. Seven years after the publication of the work of Maekawa et al. (2013), it is interesting to verify if the reasons for implementing and maintaining the standard remain the same or not. The authors of the first study reinforce the need for research to update data on the subject. Indeed, Maekawa et al. (2013) updated the research of Lima, Resende and Hasenclever (2000) and Pinto, Carvalho and Linda (2008). Additionally, in the time gap between this study and the previous one, a new version of ISO 9001 was published in 2015. Third, the data analysis of this research is conducted to understand what the most significant reasons for ISO 9000 adoption are; that is, the reasons that embrace most of variance and, because of this, Exploratory Factor Analysis was used. Thus, the analysis technique used in this research differs from the previous study. In short, this study complements the research of Maekawa et al. (2013) and does not overlap with it. 
Focusing on companies from United Arab Emirates, the study of Zaramdini (2007), should be mentioned. Considering the version of 2000 of ISO 9001, the author aimed to understand the reasons for companies to implement it and the benefits observed. For this, 220 quality managers indicated their agreement level for each reason and benefit. The collected data were statistically treated and, according to their results, the most relevant reasons for the standard adoption were related to internal issues of processes, procedures and products improvements.

Focusing on Greece's economy context, a first study to be mentioned is the research conducted by Gotzamani and Tsiotras (2002). Although not recent, the authors concluded that the main reasons that led Greek companies to adopt a quality management system were related to external pressure from customers, and certification use of competitors. This fact did not allow a correct implantation of the quality management system and it led to low efficiency of the processes. A little later and considering the 2008 version of the standard Psomas (2013) performed a survey with 100 service providers companies to understand the real motives of these companies to implement ISO 9001. Their findings showed that the companies analysed adopted and maintained the certification aiming to satisfy their customers, to prevent noncompliance and, mainly, to continuously improve. In a complementary study with 163 Greek companies with ISO 9001 certifications, Psomas and Antony (2015) verified that several critical factors for the success of ISO 9001 were related to motivations issues. Ismyrlis and Moschidis (2015) also analysed the motivations for Greek companies to adopt ISO 9001, but they highlighted external motivations, such as corporate image and customer satisfaction.

Sun et al. (2019) conducted a study of 413 Chinese companies with ISO 9001 certification and statistically proved that the reasons for implementation, the 
commitment of management, the existing barriers in relation to employees, and the level of investments impact the effectiveness of the quality management system in different ways. Also in Chinese companies context, a previously research performed by Zeng, Tian and Tam (2007) with 156 organizations showed the main barriers faced by the companies, short-sighted goal for getting certified and, over-expectation on ISO 9001 standard, were the barriers most cited by the respondents.

Djofack and Camacho (2017) focused on the impacts and motivations related to ISO 9001 implementations and maintenance for 120 Spanish tourism companies. According to their study, the main motivations are related to the improvements of products and services offered to customers.

For the reality of companies from Australia and New Zealand, Prajogo (2011) analysed 328 organizations to verify their benefits and motivations to adopt ISO 9001. The author concluded that internal motives improves the implementation process and generate better results.

Considering the presented context, it is possible to note that the reasons that lead companies to adopt and maintain a quality management system along the lines disseminated by ISO 9001 are still characterized as plausible study gaps and studies on this issue can greatly contribute to debates expansion. The dynamic nature of the standard, which is updated from time to time, requires updating the information. In this sense, this study aims to contribute with the literature, focusing on Brazilian reality. Thus, this research aims to better understand the most significant reasons that lead Brazilian companies to adopt and maintain ISO 9001 quality management systems, as well as to make comparisons with previous studies conducted in other countries and in Brazil, in order to confirm or contradict findings. The focus on Brazilian reality can be explained by: (1) the relevance of its economy in world scene; (2) the participation of 
its companies in the global market; and (3) the need to enhance Brazilian companies' international competitiveness (WEF 2018). . Another aspect to be mentioned is the amount of ISO 9001:2015 certificates emitted for Brazilian companies (ISO 2019).

In addition to this introduction, which contextualized the research and presented the theoretical background related to the theme, this article is composed of three more sections. The second section is dedicated to the presentation of the methodological procedures used in the research, highlighting the theoretical model used for research construction and technical instruments for data analysis. Section 3 is dedicated to results presentation and associated discussions. Section 4 presents the conclusions and final considerations, followed by the references used for the article's development.

\section{Methodological procedures and framework to construct questionnaire}

To perform this research, five stages were conducted as shown in Figure 1.

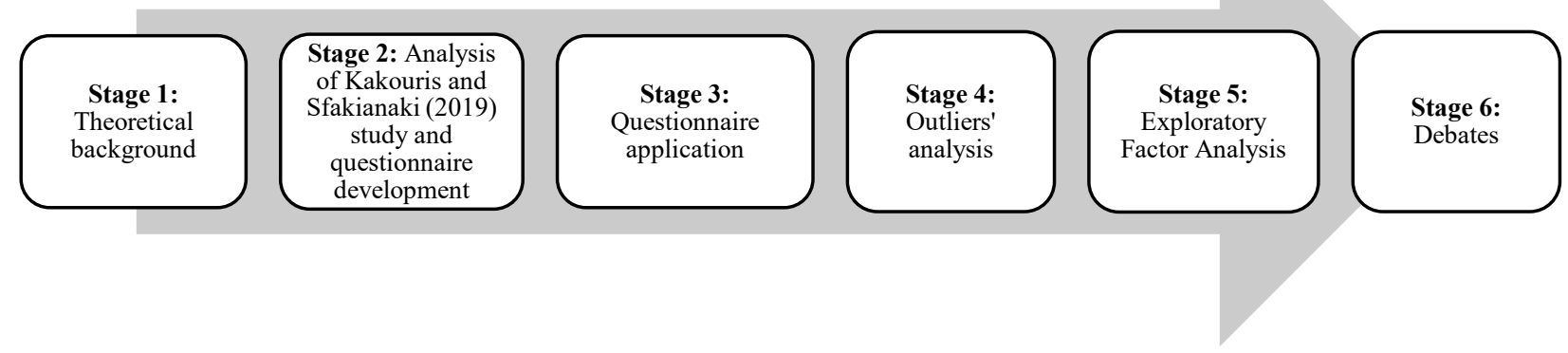

Figure 1. Research stages. Source: Authors.

As previous mentioned, the first stage was to verify in the literature the background regarding the reasons for companies to implement ISO 9001. For this first analysis, international databases were used. The databases used were: Emerald Insight, Science Direct, Taylor and Francis, and Scopus. The terms of search were: "quality", “motivation", "motives", "implementation", "ISO 9001”. The second stage followed 
was to analyse the study conducted by Kakouris and Sfakianaki (2019). This research was used to base the questionnaire for a survey with professionals. The mentioned study was used to develop the questionnaire because, analysing the literature, Kakouris and Sfakianaki (2019)'s research contemplated the principal motives to implement and maintain ISO 9001. The motives used to develop this questionnaire are presented in Table 1.

Table 1. Motives for ISO 9001 implementation. Source: Adapted from (Kakouris and Sfakianaki 2019).

\begin{tabular}{l|c}
\hline Var & Motives \\
\hline V1 & Improvements in internal processes \\
V2 & Commitment to quality \\
V3 & Improvement in products consistency \\
V5 & Customer requirements \\
V6 & Prove for customers the recognition of company's processes through an international standard \\
V7 & Opportunities for export, internationalize and access foreign markets \\
V8 & Overcome commercial barriers \\
V9 & Minimize compliance costs \\
\hline
\end{tabular}

In the third stage, the questionnaire was applied for the mentioned professionals. Before the application, the survey was authorized by the university's Ethics Committee. In the survey, the respondents needed to evaluate in a 5-point scale (totally disagree, disagree, indifferent, agree, totally agree) their agreement regarding each motive why their companies implement ISO 9001. The survey was performed for two months. After data collection, the first analysis conducted (stage 4) was outliers' identification and elimination via Boxplot chart. This chart shows data symmetry and dispersal, which enables outliers' identification (Marmolejo-Ramos and Siva Tian 2010).

In the fifth stage, Exploratory Factor Analysis (EFA) was performed to verify the variables that can summarizes the information and lose the least possible data. Additionally, the variables were grouped in factors. According the guidelines from Hair 
et al. (2009), Fávero et al. (2009), Field et al. (2012) and Malhotra (2012), EFA may be performed in seven steps, as presented in Figure 2.

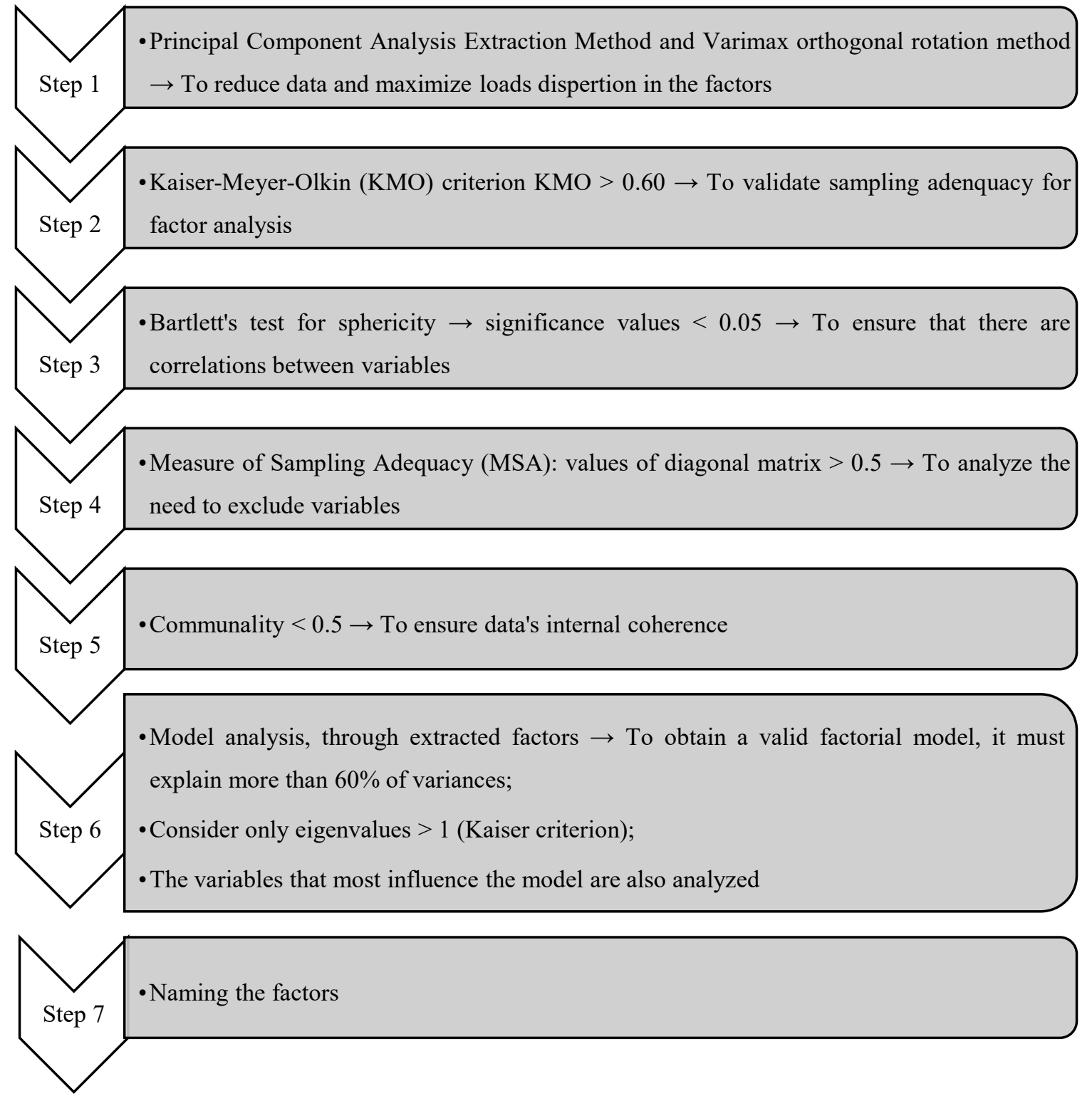

Figure 2. EFA steps. Source: Adapted from (Field, Miles, and Field 2012; Malhotra 2012; Hair et al. 2009; Fávero et al. 2009).

After EFA validation, debates considering the literature about the thematic is performed in the sixth stage of this research. The next section presents the results of these methodological procedures. 


\section{Results and debates}

\subsection{Sample characterization}

The survey was performed over two months and obtained 87 answers. However, 14 respondents were not working in companies with ISO 9001:2015 certification. Since this was a pre-requisite for respondents, these 14 answers were removed from the sample before data analysis. Thus, 73 respondents were used as the sample of this research. In this sample, $42 \%$ of the respondents have up to 10 years of professional experience; $38 \%$ of the have between 11 and 20 years of experience; and $19 \%$ were professionals with more than 20 years of experience.

Regarding their profession, most of the respondents are quality engineers, analysts, managers, and auditors and coordinators of quality management systems. It is important to highlight that all respondents have an academic degree and most of them are post-graduated. Another important feature to present is the time that the companies have ISO 9001. In the sample, the organization that implemented the standard for the longest time did it in 1988. In relation to the amount of companies per year, 2000 was the date with the highest number of first implementation, 9 companies $(12.32 \%$ of the total sample). As previously mentioned, only respondents that currently work in companies that have ISO 9001 were considered, since the focus of this research is the most recent version of ISO 9001. 


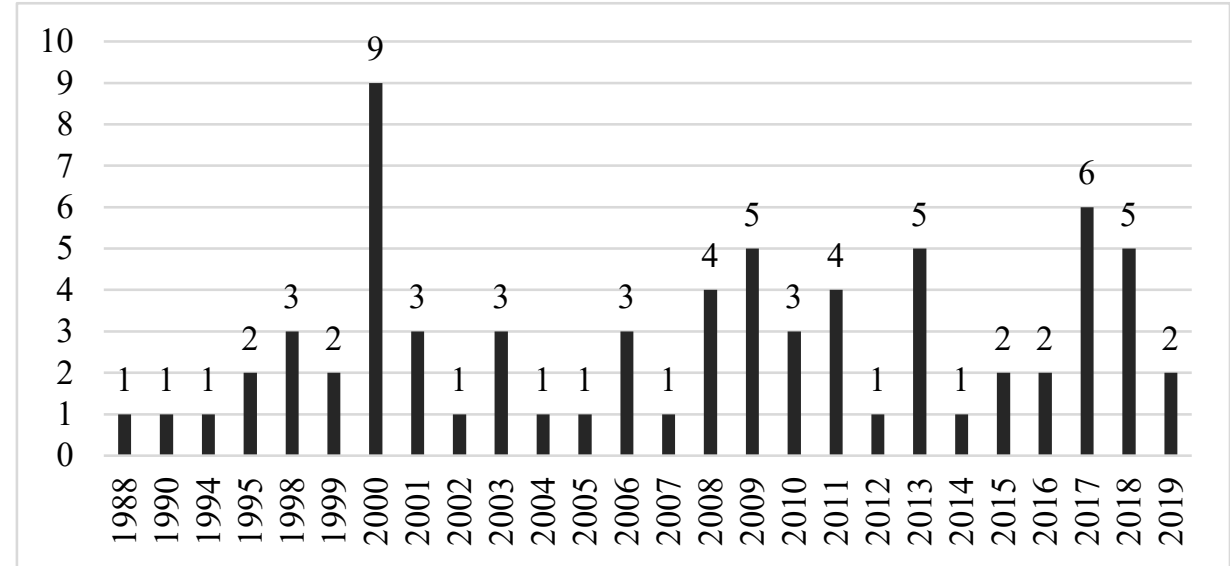

Figure 3. Year of the first ISO 9001 implementation in respondents' companies.

\subsection{Outliers' analysis}

As it was mentioned in the methodological procedures, the first data analysis performed was to identify outliers. For this, Boxplot was used. As it is shown in Figure 4, twelve respondents were eliminated from the sample, since they were identified as outliers. 


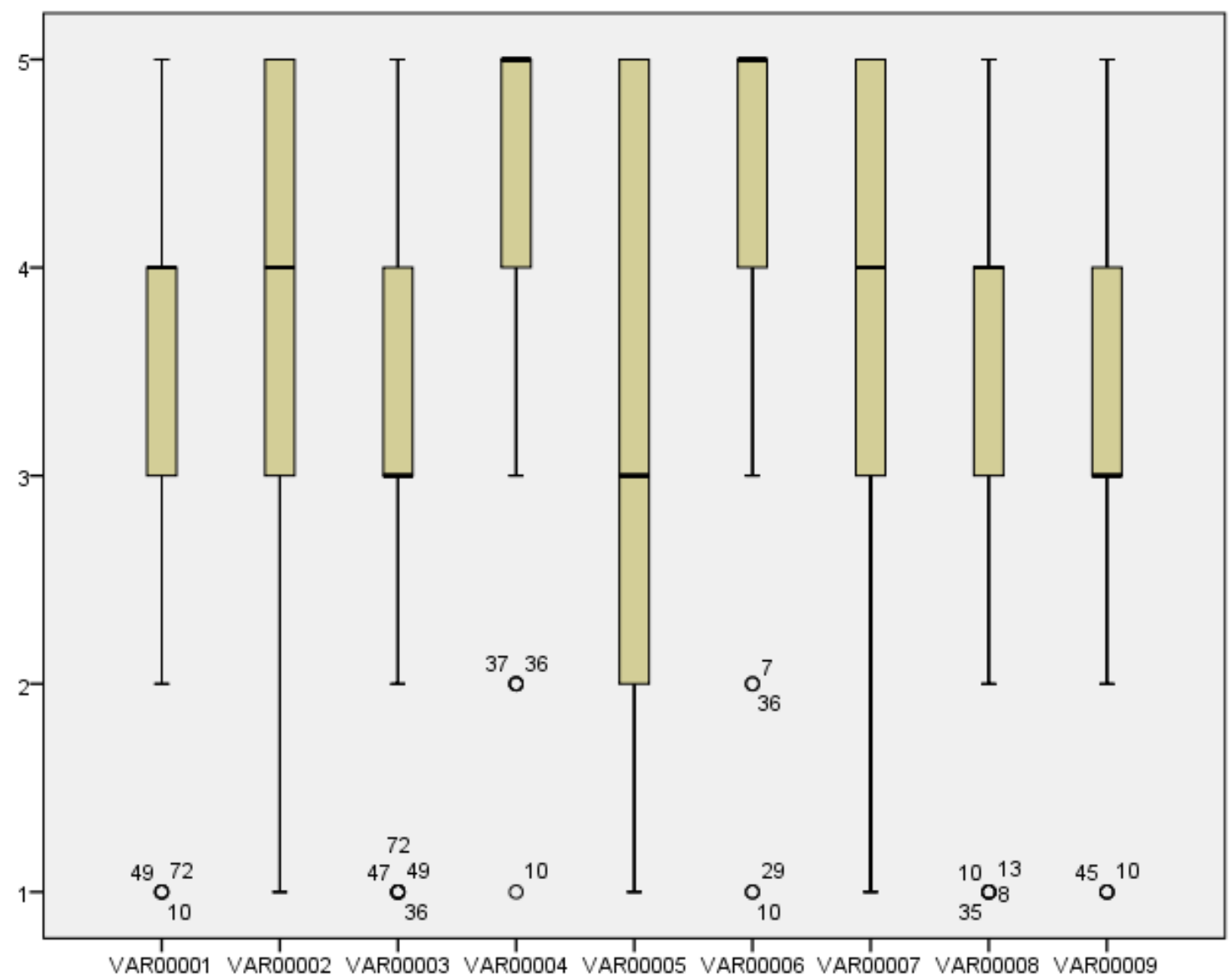

Figure 4. Outliers' analysis.

\subsection{Exploratory Factor Analysis}

In the first round of EFA, the variable 5 was eliminated in step 4, since its Measures of Sampling Adequacy (MSA) was lower than 0.5 (0.483). MSA measures sampling adequacy for each variable in the model and for the complete model, showing if the factor analysis is appropriate (Hair et al. 2009). The Anti-image matrix of this round is presented in Table 2. After this elimination, a new round was started. 
Table 2. Anti-image matrix in the first round

\begin{tabular}{ccccccccccc}
\hline & & V1 & V2 & V3 & V4 & V5 & V6 & V7 & V8 & V9 \\
\hline & V1 & $.740^{\mathrm{a}}$ & -.263 & -.360 & .302 & -.066 & .016 & -.082 & .033 & -.544 \\
& V2 & -.263 & $.785^{\mathrm{a}}$ & -.222 & .056 & .200 & -.238 & .279 & -.154 & -.217 \\
& V3 & -.360 & -.222 & $.850^{\mathrm{a}}$ & -.090 & -.104 & -.091 & -.260 & -.031 & -.119 \\
Anti-image & $\mathbf{V 4}$ & .302 & .056 & -.090 & $.571^{\mathrm{a}}$ & .027 & -.274 & -.117 & -.239 & -.269 \\
Correlation & V5 & -.066 & .200 & -.104 & .027 & $.483^{\mathrm{a}}$ & -.024 & .134 & -.341 & -.005 \\
& V6 & .016 & -.238 & -.091 & -.274 & -.024 & $.612^{\mathrm{a}}$ & -.129 & -.024 & .215 \\
& V7 & -.082 & .279 & -.260 & -.117 & .134 & -.129 & $.634^{\mathrm{a}}$ & -.394 & .015 \\
& V8 & .033 & -.154 & -.031 & -.239 & -.341 & -.024 & -.394 & $.676^{\mathrm{a}}$ & .032 \\
& V9 & -.544 & -.217 & -.119 & -.269 & -.005 & .215 & .015 & .032 & $.765^{\mathrm{a}}$ \\
\hline
\end{tabular}

${ }^{\text {a }}$ Measures of Sampling Adequacy (MSA)

In the second round, variable 6 was eliminated, due to its communality value $(0.375<0.5)$. Table 3 presents the communality values obtained in this round. After eliminating variable 6 , a new round was started.

Table 3. Communality values in the second round.

\begin{tabular}{cccccc}
\hline & Initial & Extraction & & Initial & Extraction \\
\hline V1 & 1.000 & .868 & $\mathrm{~V} 6$ & 1.000 & .375 \\
V2 & 1.000 & .703 & $\mathrm{~V} 7$ & 1.000 & .560 \\
V3 & 1.000 & .772 & $\mathrm{~V} 8$ & 1.000 & .586 \\
V4 & 1.000 & .554 & $\mathrm{~V} 9$ & 1.000 & .790 \\
\hline
\end{tabular}

In the third round, EFA was validated. Thus, this round will be entirely detailed. In the first step, Principal Component Analysis Extraction Method and Varimax orthogonal rotation method were used to reduce data and maximize loads dispersion. To validate the analysis, KMO test (second step) and Bartlett's test of sphericity (third step) were evaluated. As it is shown in Table 4, both steps were validated, since KMO is higher than 0.6 and Bartlett's test of sphericity presented significance values lower than 0.05, as recommended by Hair et al. (2009) and Fávero et al. (2009). 
Table 4. KMO and Bartlett's Test

\begin{tabular}{ccc}
\hline \multicolumn{3}{c}{ KMO and Bartlett's Test } \\
\hline & KMO & 0.761 \\
Bartlett's test of & Approx. Chi-Square & 193.056 \\
sphericity & df & 21 \\
& Sig. & .000 \\
\hline
\end{tabular}

The fourth step focused on values of the diagonal from Anti-image matrix to analyse the correlations between variables. As it is presented in Table 5, all MSA values were higher than 0.5, which validates this step (Hair et al. 2009).

Table 5. Anti-image matrix in the third round

\begin{tabular}{rlrllllll}
\hline & & V1 & V2 & V3 & V4 & V7 & \multicolumn{1}{c}{ V8 } & \multicolumn{1}{c}{ V9 } \\
\hline & V1 & $.730^{\mathrm{a}}$ & -.260 & -.370 & .321 & -.073 & .012 & -.562 \\
V2 & -.260 & $.854^{\mathrm{a}}$ & -.236 & -.014 & .238 & -.105 & -.179 \\
Anti-image & $\mathbf{V 3}$ & -.370 & -.236 & $.843^{\mathrm{a}}$ & -.119 & -.265 & -.074 & -.103 \\
Correlation & $\mathbf{V 4}$ & .321 & -.014 & -.119 & $.531^{\mathrm{a}}$ & -.164 & -.264 & -.224 \\
& V7 & -.073 & .238 & -.265 & -.164 & $.636^{\mathrm{a}}$ & -.382 & .044 \\
& V8 & .012 & -.105 & -.074 & -.264 & -.382 & $.705^{\mathrm{a}}$ & .041 \\
& V9 & -.562 & -.179 & -.103 & -.224 & .044 & .041 & $.790^{\mathrm{a}}$ \\
\hline
\end{tabular}

${ }^{a}$ Measures of Sampling Adequacy (MSA)

In step five, variables communalities were validated. As it can be verified in Table 6, all variables presented communality values higher than 0.5 (Malhotra 2012; Hair et al. 2009).

Table 6. Communality values in the third round

\begin{tabular}{cccccc}
\hline & Initial & Extraction & & Initial & Extraction \\
\hline V1 & 1.000 & .865 & $\mathrm{~V} 7$ & 1.000 & .633 \\
V2 & 1.000 & .717 & $\mathrm{~V} 8$ & 1.000 & .661 \\
V3 & 1.000 & .771 & $\mathrm{~V} 9$ & 1.000 & .786 \\
V4 & 1.000 & .554 & & & \\
\hline
\end{tabular}

The data required to conduct step six is presented in Table 7. Considering the factors with eigenvalues higher than 1 , it is possible to verify that the factorial model 
explains more than $60 \%$ of the variance $(71.086 \%)$, which validates the model

(Malhotra 2012; Hair et al. 2009).

Table 7. Total Variance Explained in the third round

\begin{tabular}{|c|c|c|c|c|c|c|c|c|c|}
\hline \multicolumn{10}{|c|}{ Total Variance Explained } \\
\hline \multirow{2}{*}{ Component } & \multicolumn{3}{|c|}{ Initial Eigenvalues } & \multicolumn{3}{|c|}{$\begin{array}{c}\text { Extraction Sums of Squared } \\
\text { Loadings }\end{array}$} & \multicolumn{3}{|c|}{$\begin{array}{c}\text { Rotation Sums of Squared } \\
\text { Loadings }\end{array}$} \\
\hline & Total & $\begin{array}{c}\% \text { of } \\
\text { Variance }\end{array}$ & $\begin{array}{c}\text { Cumulative } \\
\%\end{array}$ & Total & $\begin{array}{c}\% \text { of } \\
\text { Variance }\end{array}$ & $\begin{array}{c}\text { Cumulative } \\
\%\end{array}$ & Total & $\begin{array}{c}\% \text { of } \\
\text { Variance }\end{array}$ & $\begin{array}{c}\text { Cumulative } \\
\%\end{array}$ \\
\hline 1 & 3.247 & 46.379 & 46.379 & 3.247 & 46.379 & 46.379 & 3.083 & 44.047 & 44.047 \\
\hline 2 & 1.730 & 24.707 & 71.086 & 1.730 & 24.707 & 71.086 & 1.893 & 27.039 & 71.086 \\
\hline 3 & .703 & 10.038 & 81.124 & & & & & & \\
\hline 4 & .526 & 7.521 & 88.645 & & & & & & \\
\hline 5 & .340 & 4.862 & 93.508 & & & & & & \\
\hline 6 & .293 & 4.181 & 97.689 & & & & & & \\
\hline 7 & .162 & 2.311 & 100.00 & & & & & & \\
\hline
\end{tabular}

In this step, it is also possible to verify the most influencing variables in the model. According to Hair et al. (2009), the most influencing factors should present loads higher than 0.6. The Rotated component matrix (Table 8) shows the better allocation of each variable in the model.

Table 8. Rotated component matrix in the third round

\begin{tabular}{ccc}
\hline \multicolumn{3}{c}{ Rotated componente matrix } \\
\cline { 2 - 3 } & \multicolumn{2}{c}{ Components } \\
\hline V1 & .930 & 2 \\
V2 & .846 & \\
V3 & .824 & \\
V4 & & .734 \\
V7 & & .785 \\
V8 & & .800 \\
V9 & .883 & \\
\hline
\end{tabular}

Through Table 7, it is possible to note that variables were allocated into two factors. This enables the researchers to name the factors based on the analysis of the variables of each factor (step 7). In this study, Factor 1 was named "Motives related to processes improvements", since it contains the variables: "Improvements in internal 
processes", "Commitment to quality", "Improvement in products consistency", and "Minimize compliance costs". This factor is responsible for explaining $46.379 \%$ of the variance of variables in the model. Factor 2, for its turn, was named "Motives related to market". The following variables were allocated in Factor 2: "Customer requirements", "Opportunities for export, internationalize and access foreign markets", "Overcome commercial barriers". This factor explains $24.707 \%$ of the variance of model's variables. Observing the percentages of variance of model's variables in these factors, it is possible to affirm that most of information about the motives are in Factor 1, thus, this factor is more relevant to explain the motives than Factor 2.

It is relevant to highlight that, through a frequency analysis (Table 9), it was possible to verify that for all variables validated, the frequencies regarding agreement or full agreement were higher than the frequencies on disagreement or full disagreement. These findings indicate that most of the respondents consider the variables analysed as motives for ISO 9001 implementation in the companies they work.

Table 9. Frequency analysis.

\begin{tabular}{cccccccc}
\hline Scale & $\mathbf{V 1}$ & $\mathbf{V 2}$ & $\mathbf{V 3}$ & $\mathbf{V 4}$ & $\mathbf{V 7}$ & $\mathbf{V 8}$ & $\mathbf{V 9}$ \\
\hline 1- Totally disagree & 3 & 4 & 5 & 1 & 11 & 4 & 3 \\
2- Disagree & 12 & 8 & 9 & 3 & 5 & 6 & 14 \\
3- Indifferent & 16 & 10 & 23 & 8 & 13 & 19 & 20 \\
4- Agree & 26 & 28 & 23 & 24 & 17 & 27 & 22 \\
5- Totally agree & 16 & 23 & 13 & 37 & 27 & 17 & 14 \\
$\begin{array}{c}\text { Frequency (agreement } \\
\text { or full agreement) }\end{array}$ & $57.53 \%$ & $69.86 \%$ & $49.32 \%$ & $83.56 \%$ & $60.27 \%$ & $60.27 \%$ & $49.32 \%$ \\
\hline
\end{tabular}

When these findings are compared with the literature presented in Section 1 of this article, there are interesting issues to be observed. First, it is possible to corroborate findings with some authors (Sun et al. 2019; Su, Dhanorkar, and Linderman 2015), since the constructs obtained via Exploratory Factor Analysis are directly related to internal and external issues. Analysing the variance embraced by each factor, it is 
possible to note that the factor titled "Motives related to processes improvements" has almost twice the value of the factor "Motives related to market", which can be considered a good result because, according to several authors (Sun et al. 2019; $\mathrm{Su}$, Dhanorkar, and Linderman 2015; Kakouris and Sfakianaki 2019; Williams 2004; Sampaio, Saraiva, and Rodrigues 2009), the internal motivations, in general, present a more significant influence on the QMS implementation stages and considerably motivate the companies..

Comparing the findings of this research with the study of Maekawa et al. (2013), that also analysed Brazilian reality, it is possible to observe concordances regarding the motivations for internal improvements and productive efficiency and complements, such as opportunities for imports, internationalization, and access to foreign markets. Thus, the results obtained in this research update some information presented by Maekawa et al. (2013) and complement others. Making comparisons with research on motivation in other countries, it is possible to observe agreement with several studies as can be seen in the examples detailed in the introductory section of this article regarding authors (Zaramdini 2007; Gotzamani and Tsiotras 2002; E. L. Psomas 2013; Sun et al. 2019; Djofack and Camacho 2017; Prajogo 2011).

\section{Final Considerations and Conclusions}

This study aimed to analyse the motives that lead Brazilian companies to implement and adopt a Quality Management System according to the requirements established by ISO 9001.

This study aimed to analyse the reasons that lead Brazilian companies to implement and adopt a Quality Management System according to the requirements disseminated by ISO 9001 standard; through the results achieved, it is possible to 
observe that this objective has been achieved. Through an Exploratory Factor Analysis of data collected from 73 companies, it was possible to conclude that the reasons are grouped into two constructs, the first is related to process improvements and the second is associated with issues linked to the market. As highlighted in the introduction, the present study complements and updates information from Maekawa et al. (2013); given the dynamic nature of ISO 9001 and its constant updates, this type of research contributes to enhance the debates on the topic.

As a limitation of this research, its exploratory character should be cited, since the sample was chosen in a non-probabilistic way; however, it should be highlighted the seriousness of the respondents in providing concise information about the reasons that led their companies to adopt and maintain a Quality Management System according to the requirements disseminated by the ISO 9001 standard. Additionally, a statistical analysis was performed to treat data based on a scientific method.

As a proposal for future studies, it is recommended to carry out analyses focused on different sectors of the economy, in order to understand specificities that may lead to specific results. In addition, comparisons among similar countries, such as BRICS (Brazil, Russia, India, China, and South Africa), can also provide interesting findings, showing differences among countries.

\section{References}

Anholon, Rosley, Osvaldo Luiz Gonçalves Quelhas, Walter Leal Filho, Jefferson de Souza Pinto, and Alexander Feher. 2016. "Assessing Corporate Social Responsibility Concepts Used by a Brazilian Manufacturer of Airplanes: A Case Study at Embraer." Journal of Cleaner Production 135. Elsevier Ltd: 740-49. doi:10.1016/j.jclepro.2016.06.169.

Anholon, Rosley, Izabela Simon Rampasso, Robert Eduardo Cooper Ordonez, Dirceu da Silva, Osvaldo Luiz Gonçalves Quelhas, and Walter Leal Filho. 2018. 
“Observed Difficulties during Implementation of Quality Management Systems in Brazilian Manufacturing Companies." Journal of Manufacturing Technology Management 29 (1): 149-67. doi:10.1108/JMTM-12-2016-0167.

Castillo-Peces, Carlos del, Carmelo Mercado-Idoeta, Miguel Prado-Roman, and Cristina del Castillo-Feito. 2018. "The Influence of Motivations and Other Factors on the Results of Implementing ISO 9001 Standards." European Research on Management and Business Economics 24 (1). AEDEM: 33-41. doi:10.1016/j.iedeen.2017.02.002.

Castka, Pavel. 2018. “Modelling Firms' Interventions in ISO 9001 Certification: A Configurational Approach.” International Journal of Production Economics 201 (May): 163-72. doi:10.1016/j.ijpe.2018.05.005.

Chou, Yen-Chun, Howard Hao-Chun Chuang, and Benjamin B.M. Shao. 2014. "The Impacts of Information Technology on Total Factor Productivity: A Look at Externalities and Innovations.” International Journal of Production Economics 158 (December). Elsevier: 290-99. doi:10.1016/J.IJPE.2014.08.003.

Djofack, Sidonie, and Marco Antonio Robledo Camacho. 2017. "Implementation of ISO 9001 in the Spanish Tourism Industry." International Journal of Quality and Reliability Management 34 (1): 18-37. doi:10.1108/IJQRM-10-2014-0151.

Fávero, Luiz Paulo Lopes, Patrícia Prado Belfiore, Fabiana Lopes Silva, Betty Lilian Chan, and Campus. 2009. Análise de Dados: Modelagem Multivariada Para Tomada de Decisões. Rio de Janeiro: Campus.

Field, A., J. Miles, and Z. Field. 2012. Discovering Statistics Using R. 3rd ed. London: SAGE.

Gotzamani, Katerina D., and George D. Tsiotras. 2002. "The True Motives behind ISO 9000 Certification: Their Effect on the Overall Certification Benefits and Long Term Contribution towards TQM." International Journal of Quality and Reliability Management 19 (2): 151-69. doi:10.1108/02656710210413499.

Hadidi, Laith, Sadi Assaf, Khalaf Aluwfi, and Hassan Akrawi. 2017. "The Effect of ISO 9001 Implementation on the Customer Satisfaction of the Engineering Design Services." International Journal of Building Pathology and Adaptation 35 (2): 176-90. doi:10.1108/IJBPA-01-2017-0004. 
Hair, Joseph F., William C. Black, Barry J. Babin, Rolph E. Anderson, and Ronald L. Tatham. 2009. Multivariate Data Analysis. Upper Saddle River: Pearson Prentice Hall.

Ismyrlis, Vasileios, and Odysseas Moschidis. 2015. "The Effects of ISO 9001 Certification on the Performance of Greek Companies: A Multidimensional Statistical Analysis.” TQM Journal 27 (1). Emerald Group Publishing Ltd.: 15062. doi:10.1108/TQM-07-2013-0091.

ISO. 2019. "International Organization for Standardization." https://www.iso.org/home.html.

Kafetzopoulos, Dimitrios, Katerina Gotzamani, and Evangelos Psomas. 2013. "Quality Systems and Competitive Performance of Food Companies.” Benchmarking 20 (4): 463-83. doi:10.1108/BIJ-08-2011-0065.

Kakouris, Andreas, and Eleni Sfakianaki. 2019. "Motives for Implementing ISO 9000 Does Enterprise Size Matter?" International Journal of Productivity and Performance Management 68 (2): 447-63. doi:10.1108/IJPPM-03-2018-0096.

Leong, G.K., D.L. Snyder, and P.T. Ward. 1990. "Research in the Process and Content of Manufacturing Strategy." Omega 18 (2): 109-22. doi:10.1016/03050483(90)90058-H.

Lima, M. A.M., M Resende, and L Hasenclever. 2000. "Quality Certification and Performance of Brazilian Firms: An Empirical Study." International Journal of Production Economics 66 (2): 143-47. doi:10.1016/S0925-5273(99)00118-8.

Lizarelli, Fabiane Letícia, José Carlos de Toledo, and Dário Henrique Alliprandini. 2019. "Relationship between Continuous Improvement and Innovation Performance: An Empirical Study in Brazilian Manufacturing Companies.” Total Quality Management \& Business Excellence, August, 1-24. doi:10.1080/14783363.2019.1653178.

Maekawa, Rafael, Marly Monteiro de Carvalho, and Otávio José de Oliveira. 2013. “Um Estudo Sobre a Certificação ISO 9001 No Brasil: Mapeamento de Motivações, Benefícios e Dificuldades.” Gestão \& Produção 20 (4): 763-79. doi:10.1590/S0104-530X2013005000003. 
Malhotra, N. K. 2012. Marketing Research: An Applied Orientation (Pesquisa de Marketing: Uma Orientação Aplicada). 6th ed. Porto Alegre: Bookman.

Marmolejo-Ramos, Fernando, and Tian Siva Tian. 2010. "The Shifting Boxplot. A Boxplot Based on Essential Summary Statistics around the Mean.” International Journal of Psychological Research 3 (1): 37. doi:10.21500/20112084.823.

Molina, Luis Miguel, Fco. Javier Lloréns Montes, and Maria Del Mar Fuentes Fuentes. 2004. “TQM and ISO 9000 Effects on Knowledge Transferability and Knowledge Transfers.” Total Quality Management \& Business Excellence 15 (7): 1001-15. doi:10.1080/14783360410001681872.

Murmura, Federica, Nicola Casolani, Lolita Liberatore, and Assia Vicentini. 2018. “An Empirical Analysis of ISO 9001:2008 Application in Italian Services and Manufacturing Companies.” Total Quality Management \& Business Excellence 29 (7-8): 786-97. doi:10.1080/14783363.2016.1237286.

Nilsson-witell, Lars, Marc Antoni, and Jens J Dahlgaard. 2005. "Continuous Improvement in Product Development Improvement Programs and Quality Principles." International Journal of Quality \& Reliability Management 22 (8): 753-68. doi:10.1108/02656710510617210.

Pinto, S.H.B, M.M. Carvalho, and L. H Linda. 2008. "Main Quality Programs Characteristics in Large Size Brazilian Companies." International Journal of Quality \& Reliability Management 25 (3): 276-91. doi:10.1108/02656710810854287.

Prajogo, Daniel I. 2011. "The Roles of Firms' Motives in Affecting the Outcomes of ISO 9000 Adoption.” International Journal of Operations and Production Management 31 (1): 78-100. doi:10.1108/01443571111098753.

Priede, Jānis. 2012. "Implementation of Quality Management System ISO 9001 in the World and Its Strategic Necessity." Procedia - Social and Behavioral Sciences 58: 1466-75. doi:10.1016/j.sbspro.2012.09.1133.

Psomas, Evangelos, and Jiju Antony. 2015. “The Effectiveness of the ISO 9001 Quality Management System and Its Influential Critical Factors in Greek Manufacturing Companies." International Journal of Production Research 53 (7). Taylor \& Francis: 2089-99. doi:10.1080/00207543.2014.965353. 
Psomas, Evangelos L. 2013. "The Effectiveness of the ISO 9001 Quality Management System in Service Companies." Total Quality Management \& Business Excellence 24 (7-8): 769-81. doi:10.1080/14783363.2013.791099.

Rampasso, Izabela Simon, Rosley Anholon, Osvaldo Luiz Gonçalves Quelhas, and Walter Leal Filho. 2017. "Primary Problems Associated with the Health and Welfare of Employees Observed When Implementing Lean Manufacturing Projects." Work 58 (3): 263-75. doi:10.3233/WOR-172632.

Rybski, Christoffer, Roland Jochem, and Laura Homma. 2017. "Empirical Study on Status of Preparation for ISO 9001:2015.” Total Quality Management \& Business Excellence 28 (9-10): 1076-89. doi:10.1080/14783363.2017.1303886.

Salem, Milad Abdelnabi. 2019. "Structural Equation Modelling of the Impact of Environmental Capabilities on Competitiveness." International Journal of Productivity and Performance Management 68 (1): 127-47. doi:10.1108/IJPPM11-2016-0259.

Sampaio, Paulo, Pedro Saraiva, and António Guimarães Rodrigues. 2009. “ISO 9001 Certification Research: Questions, Answers and Approaches.” International Journal of Quality and Reliability Management 26 (1): 38-58. doi:10.1108/02656710910924161.

Santos, Gilberto, Manuel Rebelo, Nuno Lopes, M. Rui Alves, and Rui Silva. 2016. "Implementing and Certifying ISO 14001 in Portugal: Motives, Difficulties and Benefits after ISO 9001 Certification." Total Quality Management \& Business Excellence 27 (11-12): 1211-23. doi:10.1080/14783363.2015.1065176.

Sfreddo, Leonardo Stertz, Guilherme Bergmann Borges Vieira, Gabriel Vidor, and Carlos Honorato Schuch Santos. 2018. "ISO 9001 Based Quality Management Systems and Organisational Performance: A Systematic Literature Review." Total Quality Management \& Business Excellence, November, 1-21. doi:10.1080/14783363.2018.1549939.

Su, Hung-Chung, Suvrat Dhanorkar, and Kevin Linderman. 2015. “A Competitive Advantage from the Implementation Timing of ISO Management Standards.” Journal of Operations Management 37 (July). Elsevier B.V.: 31-44. doi:10.1016/j.jom.2015.03.004. 
Sun, Xiaojing, Decheng Wen, Dongwei Yan, and Yaping Li. 2019. "Developing and Validating a Model of ISO 9001 Effectiveness Gap: Empirical Evidence from China." Total Quality Management \& Business Excellence 30 (sup1). Taylor \& Francis: S274-90. doi:10.1080/14783363.2019.1665867.

Tang, S.L., and C.W. Kam. 1999. "A Survey of ISO 9001 Implementation in Engineering Consultancies in Hong Kong.” International Journal of Quality \& Reliability Management 16 (6): 562-74. doi:10.1108/02656719910249810.

Toke, Lalit K., and Shyamkumar D. Kalpande. 2020. "Total Quality Management in Small and Medium Enterprises: An Overview in Indian Context.” Quality Management Journal 27 (3). Taylor \& Francis: 159-75. doi:10.1080/10686967.2020.1767008.

Tomic, Branislav, and Vesna K. Spasojevic Brkic. 2019. "Customer Satisfaction and ISO 9001 Improvement Requirements in the Supply Chain.” TQM Journal 31 (2). Emerald Group Publishing Ltd.: 222-38. doi:10.1108/TQM-07-2017-0072.

WEF. 2018. “The World's Biggest Economies in 2018.” World Economic Forum. https://www.weforum.org/agenda/2018/04/the-worlds-biggest-economies-in-2018/.

Wilcock, Anne E., and Kathryn A. Boys. 2017. "Improving Quality Management: ISO 9001 Benefits for Agrifood Firms.” Journal of Agribusiness in Developing and Emerging Economies 7 (1): 2-20. doi:10.1108/JADEE-12-2014-0046.

Willar, Debby, Vaughan Coffey, and Bambang Trigunarsyah. 2015. "Examining the Implementation of ISO 9001 in Indonesian Construction Companies." The TQM Journal 27 (1): 94-107. doi:10.1108/TQM-08-2012-0060.

Williams, Joseph A. 2004. "The Impact of Motivating Factors on Implementation of ISO 9001:2000 Registration Process.” Management Research News 27 (1/2): 74 84. doi:10.1108/01409170410784365.

Wilson, John P., and Larry Campbell. 2016. "Developing a Knowledge Management Policy for ISO 9001: 2015.” Journal of Knowledge Management 20 (4): 829-44. doi:10.1108/JKM-11-2015-0472.

—. 2018. "ISO 9001:2015: The Evolution and Convergence of Quality Management and Knowledge Management for Competitive Advantage.” Total 
Quality Management \& Business Excellence 0 (0). Taylor \& Francis: 1-16. doi:10.1080/14783363.2018.1445965.

Youssef, Mohamed A., and Eyad M. Youssef. 2018. "The Synergistic Impact of ISO 9000 and TQM on Operational Performance and Competitiveness." International Journal of Quality and Reliability Management 35 (3): 614-34. doi:10.1108/IJQRM-02-2016-0024.

Zaramdini, Walid. 2007. “An Empirical Study of the Motives and Benefits of ISO 9000 Certification: The UAE Experience.” International Journal of Quality and Reliability Management 24 (5): 472-91. doi:10.1108/02656710710748358.

Zeng, S.X., P. Tian, and C.M. Tam. 2007. "Overcoming Barriers to Sustainable Implementation of the ISO 9001 System.” Managerial Auditing Journal 22 (3): 244-54. doi:10.1108/02686900710733125.

Zrymiak, Dan. 2017. “Achieving Customer Experience Excellence through a Quality Management System.” Quality Management Journal 24 (1). Informa UK Limited: 46-46. doi:10.1080/10686967.2017.11918500. 